
\title{
25 Research Soure \\ Multidrug-Resistant Bacteria with ESBL Genes: A Growing Threat Among HIV Patients in Nepal
}

Riju Maharjan

Tribhuvan University

Anup Bastola

Sukraraj Tropical and Infectious Disease Hospital

Nabaraj Adhikari

Tribhuvan University

Komal Raj Rijal

Tribhuvan University

Megha Raj Banjara

Tribhuvan University

Prakash Ghimire

Tribhuvan University

Upendra Thapa Shrestha ( $\square$ upendrats@gmail.com )

Tribhuvan University

\section{Research Article}

Keywords: HIV, Lower respiratory tract infection, ESBL, blaCTX-M, blaTEM

Posted Date: December 21st, 2021

DOI: https://doi.org/10.21203/rs.3.rs-1103790/v1

License: (c) (i) This work is licensed under a Creative Commons Attribution 4.0 International License.

Read Full License 


\section{Abstract \\ Background}

Bacterial opportunistic infections are quite common in HIV patients. Besides HIV-TB coinfection, lower respiratory tract infections by multidrug-resistant bacteria cause significant morbidity and mortality among HIV patients. This study was done to evaluate the bacterial coinfection of LRT and detect plasmid-mediated $b / a_{\mathrm{TEM}}$ and $b / a_{\mathrm{CTX}-\mathrm{M}}$ genes among Extended-Spectrum $\beta$-Lactamase (ESBL) producing isolates from sputum samples in HIV patients.

\section{Methods}

A total of 263 sputum samples from HIV-positive cases were processed with standard microbiological methods to isolate and identify the possible pathogens. The identified bacterial isolates were assessed for antibiotic susceptibility pattern by using modified Kirby Bauer disk diffusion method following Clinical Laboratory Standard Institute (CLSI) guidelines. Plasmid DNA was extracted from multidrug-resistant and ESBL producers for screening of ESBL genes; $b / a_{\mathrm{CTX}-\mathrm{M}}$ and $b / a_{\mathrm{TEM}}$ by conventional PCR method using specific primers.

\section{Results}

Of 263 sputum samples, 67 (25.48\%) were culture positive showing Klebsiella pneumoniae; 17(25.37\%) as the most predominant one. A higher rate of infection (4/8,50\%) was observed among old-aged people of $61-70$ years, whereas no infection was observed below 20 years. About 30.0\% (15/50) of smokers, $32.86 \%(23 / 70)$ cases with previous pulmonary tuberculosis and $52.38 \%(11 / 21)$ with CD 4 count $<200$ cells/ $\mu$ l were found to be susceptible to LRT Is. Among 53 bacterial isolates, $52.83 \%(n=28)$ were multidrug-resistant and $43.4 \%(n=23)$ were ESBL producers. All ESBL producers were sensitive to Colistin and Polymyxin B. Of 23 ESBL producers, $47.83 \%(11 / 23)$ and $8.6 \%(2 / 23)$ possessed only bla $a_{C T X-M}$ and bla $a_{\mathrm{TEM}}$ genes respectively and $43.48 \%(10 / 23)$ possessed both ESBL genes.

\section{Conclusion}

The increasing rate of MDR bacterial infections mainly ESBL producers of LRTIs causes difficulty in the management of diseases leading to high morbidity and mortality of HIV patients.

\section{Background}

Human Immunodeficiency Virus (HIV), since first confirmed in 1981, has killed more than one million people worldwide. Thirty-eight million people were living with HIV at the end of 2019 with 1.8 million 
people becoming newly infected (1). The virus destroys the function of immune cells like helper T cells specifically CD4+ T cells, macrophages and dendritic cells reducing the significant number of CD4 cell count (2) leading to an increased number of opportunistic infections. Although $67 \%$ of total HIV patients were covered with antiretroviral therapy (ART) globally, the secondary infections by fungi, bacteria, parasites and other viruses have not been reduced as expected. Bacterial and fungal infections are quite common opportunistic infections followed by parasitic and viral infections (3). The mortality rate of HIV patients is significantly higher in HIV and tuberculosis (TB) coinfection, however, the bacterial lower respiratory tract infections (LRTIs) other than by Mycobacterium tuberculosis can't be avoided in people living with HIV-AIDS (PLHA). Streptococcus pneumoniae, Hemophilus influenza, Pseudomonas aeruginosa, Staphylococcus aureus, Klebsiella pneumoniae, Acinetobacter spp are some common organisms causing LRTIs (4). The antimicrobial resistance among those bacterial pathogens is a matter of concern nowadays due to the increase in the ineffectiveness of antibiotic therapy in PLHA leading to higher mortality (5).

In the context of Nepal, 10,000-15,000 people die of AIDS-related infections every year due to a lack of effective treatment and care (6). In most developing countries, the lack of proper diagnosis and treatment of secondary bacterial infection is a key to deteriorating the quality of life of PLHA. A very few studies have been documented on such infections and their impacts on PLHA in Nepal. Hence, this study was conducted to identify possible bacterial pathogens causing LRTI in PLHA and their antibiogram phenotypically and genotypically.

\section{Methods}

\section{Study design, site and duration}

A hospital-based prospective cross-sectional study was designed and was conducted in Antiretroviral Treatment (ART) center, Sukraraj Tropical and Infectious Disease Hospital, Teku, Kathmandu, Nepal from February to August 2019. Sample collection and processing were done in the same hospital and the further process of genome extraction and gene detection was done in Central Department of Microbiology, Tribhuvan University, Kathmandu.

\section{Inclusion and exclusion criteria}

All age groups of both sexes living with HIV under ART who gave written consent were enrolled in this study. However, among them, if infected with tuberculosis were excluded from the study.

\section{Sample size}

The sample size was calculated to be 255 based on the prevalence rate of bacterial lower respiratory tract infection in HIV patients i.e. 21\% as described by Kandati et al 2016 (7). For this study, a total of 263 sputum samples were collected during the study period.

\section{Sample collection, transportation and processing}


A sputum sample was collected from the confirmed HIV people visiting ART center at the hospital for ART. Sterile vials with a wide mouth and tight lid were provided to the participants for the collection of sputum. Participants were instructed to take a deep breath and then to expectorate cough (8). The sputum samples collected were transported to the Microbiology laboratory and processed. The quality of sputum was checked macroscopically for the presence of mucopurulent part for the acceptance of the sample.

\section{Sputum culture}

Mucopurulent sputum was cultured on MacConkey Agar (MA), Blood Agar (BA), and Chocolate Agar (along with 10-unit Bacitracin disk) and incubated at $37^{\circ} \mathrm{C}$ for 24 hours. Incubated plates were examined for the presence of distinct colonies and identification was done by using standard microbiological protocols including their colony morphology on different culture media, microscopically by Gram staining and various biochemical tests (8).

For identification of $H$. influenza satellitism test was performed. A loopful of suspected colonies of Haemophilus colonies was mixed in about $2 \mathrm{ml}$ of sterile physiological saline. Using a sterile swab stick, inoculate the organism suspension on a plate of blood agar and a pure culture of $S$. aureus was streaked across the inoculated blood agar plate. It was then incubated in a $\mathrm{CO}_{2}$ enriched atmosphere at 35 to $37^{\circ} \mathrm{C}$ for 18-24 hours. The culture plate was examined for growth and satellite colonies (8).

\section{Antibiotics susceptibility test}

Antibiotic susceptibility patterns of the organism were performed by using the modified Kirby Bauer disk diffusion method recommended by CLSI 2019 (9). The antibiotics used were Amoxicillin (10 $\mu \mathrm{g})$, Piperacillin/tazobactam (PIT, 100/10 mcg), Chloramphenicol (C, $30 \mathrm{mcg}$ ), Ciprofloxacin (CIP, $5 \mathrm{mcg}$, Gentamycin (GEN, $10 \mathrm{mcg}$ ), Tetracycline (30 mcg), Imipenem (IMP, $10 \mathrm{mcg}$ ), Amoxycillin/clavulanic acid (AMC, 20/10 mcg), Cefepime (CPM, 30mcg), Cotrimoxazole (COT, $25 \mathrm{mcg}$ ), Ceftazidime (CTZ, $30 \mathrm{mcg}$ ), Ceftriaxone (CTR, $30 \mathrm{mcg}$ ), Polymyxin-B (PB, 300 units) and Colistin (CL $10 \mathrm{mcg}$ ). The isolates that are resistant to at least 1 agent in $\geq 3$ antimicrobial categories are considered as MDR (10). Subsequently, the prevalence of MDR bacteria was determined.

\section{Screening and confirmation of extended-spectrum $\beta$ - lactamase (ESBL)}

Those isolates resistant to antibiotics; Ceftazidime $(30 \mu \mathrm{g})$, Ceftriaxone $(30 \mu \mathrm{g})$ were considered as potential ESBL producers and the confirmatory test was performed by double disk diffusion method using Ceftazidime and Ceftazidime clavulanic acid. More than $5 \mathrm{~mm}$ zone of diameter around Ceftazidime-clavulanic acid disc than Ceftazidime disc alone was confirmed to be an ESBL producer (9).

\section{Detection of metallo $\beta$-lactamase (MBL)}

Two Imipenem discs were placed on an MHA plate inoculated with a test organism (bacterial density equivalent to 0.5 Mac-farland Standard). A $5 \mu$ of EDTA $(0.5 \mathrm{M}, \mathrm{pH}=8.0)$ solution was added to one of the 
Imipenem discs and incubated for $16-18$ hours at $37^{\circ} \mathrm{C}$. An increased zone of diameter $(>7 \mathrm{~mm})$ around Imipenem and EDTA disc than Imipenem alone was confirmed to be MBL positive (9).

\section{Bacterial plasmid DNA extraction}

Plasmid DNA from MDR isolates was extracted manually by phenol-chloroform method (alkaline lysis method) and visualized by running Agarose gel electrophoresis as described by Sambrook, 1989 and Thapa Shrestha and Adhikari 2014 (11, 12).

Molecular detection of bla $\mathrm{C}_{\mathrm{CTX}-\mathrm{M}}$ and bla $\mathrm{TEM}_{\mathrm{TEM}}$ gene

A set of primers for each gene had been selected from the previous studies and verified on NCBI BLAST. A set of primers (Forward: 5'-TTTGCGATGTGCAGTACCAGTAA-3' and reverse: 5'-CTCCGCCTGCCGGTTTTAT3 ) as described in Edelsteint et al 2003 (13) were used for bla $a_{\text {CTX-M }}$ gene. Similarly, for the bla $a_{\text {TEM, }}$ a set of primers (Forward: 5'-GAGACAATAAGGGTGGTAAAT-3' and reverse: 5'-AGAAGTAAGTTGGCAGCAGTG-3') as mentioned in Sharma et al. 2013 were used (14). A conventional PCR was used to amplify the b/a $a_{\mathrm{TEM}}$ and bla $a_{\text {CTX-M }}$ genes. A PCR reaction mixture was prepared to contain $12.5 \mu$ l the master mix from Qiagen, 0.5 $\mu \mathrm{l}$ of each primer, $3 \mu \mathrm{l}$ template DNA and $8.5 \mu \mathrm{l}$ PCR grade water (13). PCR Amplification reactions were run at initial denaturation of $95^{\circ} \mathrm{C}$ for 15 minutes; followed by 35 cycles of denaturation at $94^{\circ} \mathrm{C}$ for 45 seconds, annealing at $55^{\circ} \mathrm{C}$ for b/a TEM genes and $56^{\circ} \mathrm{C}$ for the bla $a_{\mathrm{CTX}-\mathrm{M}}$ gene for $30 \mathrm{~s}$, extension at $72^{\circ} \mathrm{C}$ for $3 \mathrm{~min}$ and a final extension at $72^{\circ} \mathrm{C}$ for $10 \mathrm{~min}$. The PCR products were analyzed on $1.5 \%$ agarose gel electrophoresis with $0.2 \mu \mathrm{g} / \mathrm{ml}$ concentration of ethidium bromide.

\section{Quality Control}

Control strain of E. coli (ATCC 25922) and Pseudomonas aeruginosa (ATCC 27853) were used as positive controls from ESBL and MBL producing strains respectively. For PCR, a previously harvested plasmid containing target genes were used as positive control and nuclease-free water as a negative control.

\section{Data management and analysis}

All the data collected from the laboratory about the isolates and demographic data collected from the questionnaire were processed and analyzed by using SPSS-21 software. The significance of the data with different variables was calculated by the Chi-square test. P-value $<0.05$ was considered as a significant result.

\section{Results}

Mode of transmission of HIV among study population: Among 263 cases, 145 (55.13\%) were male and 118 (44.87\%) were female. Heterosexual activities were the most dominant route of transmission accounting for $78.33 \%$ whereas the least rate of transmission, $0.76 \%(n=2)$ was observed via a vertical route from mother to infants (Figure 1). 


\section{Bacterial growth according to age and gender of patients}

Out of 263 sputum samples from HIV-positive individuals, 67 (25.48\%) samples were positive for bacterial growth. The bacterial infection of LRT was found highest (50\%) in the age group 61-70 years followed by $40 \%(n=10)$ among the male of age group 51-60 years. No infection was observed below 20 years (Table 1).

Table 1

Age and sex-wise distribution of Microbial growth

\begin{tabular}{|c|c|c|c|c|c|}
\hline \multirow{2}{*}{$\begin{array}{l}\text { Age group } \\
\text { (years) }\end{array}$} & \multicolumn{2}{|l|}{ Male } & \multicolumn{2}{|l|}{ Female } & \multirow{2}{*}{$\begin{array}{l}\text { Total number } \\
\text { (growth \%) }\end{array}$} \\
\hline & $\begin{array}{l}\text { No. of } \\
\text { sample }\end{array}$ & Growth (\%) & $\begin{array}{l}\text { No. of } \\
\text { sample }\end{array}$ & $\begin{array}{l}\text { Growth } \\
\text { (\%) }\end{array}$ & \\
\hline Below 20 & 3 & 0 & 1 & 0 & $4(0)$ \\
\hline $21-30$ & 29 & 8 (27.59) & 20 & $5(25)$ & $49(26.53)$ \\
\hline $31-40$ & 40 & $9(22.5)$ & 52 & $\begin{array}{l}12 \\
(23.08)\end{array}$ & $92(22.83)$ \\
\hline $41-50$ & 42 & $10(23.81)$ & 32 & $\begin{array}{l}10 \\
(31.25)\end{array}$ & 74 (27.03) \\
\hline $51-60$ & 25 & $10(40)$ & 11 & 1 (9.09) & $36(30.56)$ \\
\hline $61-70$ & 6 & $3(50)$ & 2 & $1(50)$ & $8(50)$ \\
\hline Total & 145 & $\begin{array}{l}40 \\
(27.59)\end{array}$ & & $\begin{array}{l}27 \\
(22.88)\end{array}$ & $263(25.48)$ \\
\hline
\end{tabular}

Bacterial co-infection and predisposing factors: Bacterial infection was observed significantly higher $(p=0.02)$ among HIV patients with CD 4 count $<200$ cells $/ \mu$ l. Similarly, bacterial infections were found to be higher among smokers and those with a history of pulmonary tuberculosis but the data was not statistically significant (Table 2). 
Table 2

Relation bacterial infection with predisposing factors

\begin{tabular}{|c|c|c|c|c|c|}
\hline \multirow{2}{*}{$\begin{array}{l}\text { Predisposing } \\
\text { factors }\end{array}$} & \multirow{2}{*}{$\begin{array}{l}\text { Status of predisposing } \\
\text { factors }\end{array}$} & \multicolumn{2}{|c|}{ Bacterial Growth } & \multirow[t]{2}{*}{ Total } & \multirow{2}{*}{$\begin{array}{l}\text { p- } \\
\text { value }\end{array}$} \\
\hline & & $\begin{array}{l}\text { Negative } \\
(\%)\end{array}$ & $\begin{array}{l}\text { Positive } \\
\text { (\%) }\end{array}$ & & \\
\hline \multirow[t]{3}{*}{ CD4 count cells/ $\mu \mathrm{l}$} & $<200$ & $10(47.62)$ & $11(52.38)$ & 21 & \multirow[t]{3}{*}{0.02} \\
\hline & $200-499$ & $56(60.22)$ & 37 (39.78) & 93 & \\
\hline & $>500$ & $130(87.25)$ & 19 (12.75) & 149 & \\
\hline Total & & $196(74.52)$ & $67(25.48)$ & 263 & \\
\hline \multirow[t]{3}{*}{ Smoking habit } & Non-smoker & $117(77.48)$ & $34(22.52)$ & 151 & \multirow[t]{3}{*}{$>0.05$} \\
\hline & Smoker & $35(70)$ & $15(30.0)$ & 50 & \\
\hline & Previous smoker & $44(70.97)$ & $18(29.03)$ & 62 & \\
\hline Total & & $196(74.52)$ & $67(25.48)$ & 263 & \\
\hline \multirow[t]{2}{*}{ History of PTB } & No cases & $149(77.20)$ & $44(22.80)$ & 193 & \multirow[t]{2}{*}{$>0.05$} \\
\hline & Cases & $47(67.14)$ & $23(32.86)$ & 70 & \\
\hline Total & & 196 (74.52) & $67(25.48)$ & 263 & \\
\hline
\end{tabular}

\section{Bacterial infection among HIV people based on their literacy and occupation}

Most of the samples (43.3\%) were from HIV people completing primary level education. Very least (1.1\%) samples were from highly educated ones. The rate of infection was found to be higher among literate people as compared to illiterate people. Likewise, bacterial infection was higher (30\%) in the individuals involving their business followed by official workers (26.6\%) (Table 3). 
Table 3

Microbial growth pattern and literacy

\begin{tabular}{|llllll|}
\hline Literacy & $\begin{array}{l}\text { Number of } \\
\text { sample }\end{array}$ & $\begin{array}{l}\text { Bacterial growth } \\
(\%)\end{array}$ & Occupation & $\begin{array}{l}\text { Number of } \\
\text { sample }\end{array}$ & $\begin{array}{l}\text { Bacterial growth } \\
\text { (\%) }\end{array}$ \\
\hline Illiterate & 85 & $26(30.59)$ & Households & 82 & $20(24.39)$ \\
\hline Primary & 114 & $28(24.56)$ & Farmer & 36 & $10(27.78)$ \\
\hline Secondary & 52 & $8(15.38)$ & Business & 50 & $15(30)$ \\
\hline $\begin{array}{l}\text { Higher } \\
\text { secondary }\end{array}$ & 9 & $3(33.33)$ & Driving & 13 & $2(15.38)$ \\
\hline Bachelors & 3 & $2(66.67)$ & Social work & 10 & $2(20)$ \\
\hline Total & 263 & $67(25.48)$ & Labor & 9 & $2(22.22)$ \\
\hline & & $\begin{array}{l}\text { Official } \\
\text { work }\end{array}$ & 38 & $10(26.32)$ \\
\hline & & Others & 25 & $6(24)$ \\
\hline
\end{tabular}

Frequency of bacterial pathogens from LRT infections: Out of 67-gram negative bacterial isolates, $K$. pneumoniae was the most predominant bacteria followed by $H$. influenzae. Acinetobacter spp was the least isolated one (Figure 2).

Antibiotic susceptibility pattern: All isolated strains of $K$. pneumoniae and $K$. oxytoca were resistant to Amoxicillin whereas all of them were sensitive to Colistin and Polymyxin B. Of 12 isolates of E. coli, 10 (83.33\%) were resistant to Amoxicillin and 9 (75\%) were resistant to third-generation cephalosporins. Similarly, the highest number of $E$. aerogenes; $8 / 9$ (88.89\%) were resistant to Amoxicillin. All isolates of $C$. frundii were also resistant to Amoxicillin (Table 4). 
Table 4

Antibiogram of bacterial isolates of Enterobacteriaceae family

\begin{tabular}{|c|c|c|c|c|c|}
\hline \multirow[t]{2}{*}{ Antibiotics used } & \multicolumn{5}{|c|}{ Number of resistant pathogens (\%) } \\
\hline & $\begin{array}{l}\text { K. pneumoniae } \\
(n=17)\end{array}$ & $\begin{array}{l}\text { K. oxytoca } \\
(n=4)\end{array}$ & $\begin{array}{l}\text { E. coli } \\
(n=12)\end{array}$ & $\begin{array}{l}\text { E. aerogenes } \\
(n=9)\end{array}$ & $\begin{array}{l}\text { C. frundii } \\
(n=6)\end{array}$ \\
\hline Amoxicillin & $17(100)$ & $4(100)$ & $\begin{array}{l}10 \\
(83.33)\end{array}$ & $8(88.89)$ & $6(100)$ \\
\hline Cotrimoxazole & $10(58.82)$ & $2(50)$ & $8(66.67)$ & $1(11.11)$ & 0 \\
\hline Ceftriaxone & $9(52.94)$ & $2(50)$ & $9(75)$ & $1(11.11)$ & 0 \\
\hline Ciprofloxacin & $4(23.53)$ & $1(25)$ & $7(58.33)$ & $1(11.11)$ & 0 \\
\hline Chloramphenicol & $3(17.65)$ & 0 & $3(25)$ & $1(11.11)$ & 0 \\
\hline Gentamycin & $2(11.76)$ & 0 & $1(8.33)$ & $1(11.11)$ & 0 \\
\hline Tetracycline & $14(82.35)$ & $3(75)$ & $7(58.33)$ & $3(33.33)$ & $3(50)$ \\
\hline Ceftazidime & $9(52.94)$ & $2(50)$ & $9(75)$ & $1(11.11)$ & 0 \\
\hline $\begin{array}{l}\text { Amoxicillin- } \\
\text { clavulanic acid }\end{array}$ & $10(58.82)$ & $2(50)$ & $9(75)$ & $2(22.22)$ & 0 \\
\hline $\begin{array}{l}\text { Piperacillin } \\
\text { tazobactam }\end{array}$ & $5(29.41)$ & $1(25)$ & $7(58.33)$ & $1(11.11)$ & 0 \\
\hline Cefepime & $5(29.41)$ & $1(25)$ & $5(41.67)$ & $1(11.11)$ & 0 \\
\hline Imipenem & $2(11.76)$ & 0 & $1(8.33)$ & $1(11.11)$ & 0 \\
\hline Polymyxin B & 0 & 0 & 0 & 0 & 0 \\
\hline Colistin & 0 & 0 & 0 & 0 & 0 \\
\hline
\end{tabular}

All strains of $P$. aeruginosa were resistant to Amoxicillin, Cotrimoxazole, Ceftriaxone, Ceftazidime, Chloramphenicol, Tetracycline, Amoxicillin-clavulanic acid, Piperacillin-tazobactam and 3/4 (75\%) of strains were resistant to Ofloxacin and Cefepime. However, all strains were sensitive to Gentamycin, Ciprofloxacin, Imipenem, Amikacin, Colistin. Likewise, all isolates of Acinetobacter spp were resistant to Amoxicillin, Cotrimoxazole, Ceftriaxone, Chloramphenicol, Tetracycline, Ceftazidime, Piperacillin and Amoxicillin-clavulanic acid and all were susceptible to Gentamycin, Imipenem, Polymyxin B and Colistin.

\section{Multidrug-resistant (MDR) and extended-spectrum $\beta$-lactamase (ESBL) producing strains}

Out of 53 bacterial isolates, 28 (52.83\%) were found multidrug-resistant. All strains of $P$. aeruginosa and Acinetobacterspp were found MDR strains whereas no strain of $C$. frundii was observed to be MDR.

Similarly, $75 \%(9 / 12)$ of E. coli, $64.71 \%(11 / 17)$ of $K$. pneumoniae and $50 \%(2 / 4)$ of K. oxytoca were also MDR strains. 
A total of $23(43.4 \%)$ isolates were found to be ESBL producers including 75\% (9/12) E. coli and all isolates of $P$. aeruginosa and Acinetobacter spp.

Out of total MDR strains, $72.73 \%(8 / 11)$ of $K$. pneumoniae and $50 \%(1 / 2)$ of $K$. oxytoca were ESBL producers. One strain of $P$. aeruginosa was also found to produce MBL.

Detection of ESBL genes: Of 53 isolates, 23 (43.4\%) possessed ESBL genes. Among them, 11 (47.83\%) harbored the bla $a_{\text {СTX-M }}$ gene (Figure 3 ) and 2 (8.69\%) contained the bla $a_{\text {TEM }}$ gene only (Figure 4). Similarly, 10 isolates $\left(43.48 \%\right.$ ) possess both bla $a_{\text {TEM }}$ and $b / a_{\text {CTX-M }}$ genes in their plasmid DNA (Table 5).

Table 5

Detection of bla $_{\mathrm{CTX}-\mathrm{M}}$ and $\mathrm{bla}_{\mathrm{TEM}} \mathrm{ESBL}$ genes among the isolates

\begin{tabular}{|c|c|c|c|c|c|c|}
\hline \multirow[t]{2}{*}{ Isolates } & \multirow[t]{2}{*}{$\mathbf{n}$} & \multirow{2}{*}{$\begin{array}{l}\text { Phenotypic } \\
\text { ESBL }\end{array}$} & \multirow{2}{*}{$\begin{array}{l}\text { Genotypic } \\
\text { ESBL }\end{array}$} & \multicolumn{3}{|c|}{ Number of amplified genes } \\
\hline & & & & $\begin{array}{l}\text { bla }_{\mathrm{CTX}-\mathrm{M}} \\
(\%)\end{array}$ & $\begin{array}{l}\text { bla } \\
(\%)\end{array}$ & $\begin{array}{l}\text { bla }_{\mathrm{CTX}} \mathrm{M}+\text { bla }_{\mathrm{TEM}} \\
(\%)\end{array}$ \\
\hline $\begin{array}{l}\text { K. } \\
\text { pneumoniae }\end{array}$ & 17 & $8(47.06)$ & $7(41.18)$ & $3(42.86)$ & 0 & $4(57.14)$ \\
\hline K. oxytoca & 4 & $1(25)$ & $2(50)$ & $1(50)$ & 0 & $1(50)$ \\
\hline E. coli & 12 & $9(75)$ & $9(75)$ & 3 (33.33) & $\begin{array}{l}2 \\
(22.22)\end{array}$ & $4(44.45)$ \\
\hline P. aeruginosa & 4 & $4(100)$ & $3(75)$ & $3(100)$ & 0 & 0 \\
\hline $\begin{array}{l}\text { Acinetobacter } \\
\mathrm{spp}\end{array}$ & 1 & $1(100)$ & $1(100)$ & $1(100)$ & 0 & 0 \\
\hline E. aerogenes & 9 & 0 & $1(11.11)$ & 0 & 0 & $1(100)$ \\
\hline C. frundii & 6 & 0 & 0 & 0 & 0 & 0 \\
\hline Total & 53 & $23(43.4)$ & $23(43.4)$ & $\begin{array}{l}11 \\
(47.83)\end{array}$ & $2(8.69)$ & $10(43.48)$ \\
\hline
\end{tabular}

\section{Discussion}

Among the different routes of HIV transmission, most of the people in this study were infected through the heterosexual route (78.33\%). Similar to this study, Chandwani et al reported the highest rate (95\%) of transmission via the heterosexual route (15). Among the infected people, almost all females were housewives and got HIV infections from their husbands. This result is also supported by Chandwani et al (15). The least rate of transmission from mother to infants might be due to an increase in awareness on HIV-AIDS and wide coverage by ART reducing the rate of transmission as recommended by WHO (1). 
Of 263 samples processed, 67 (25.5\%) were found culture positive. Similar studies by Chakma et al and Ojha reported higher rates of bacterial infection among HIV people accounting for $78.3 \%$ and $46.6 \%$ of respectively $(4,16)$. Likewise, Oja-Bola and Oluyege reported $55.6 \%$ of HIV people associated with pneumonia (5) and $52.83 \%$ by Ramana et al (17). The comparatively lower rate of bacterial infections might be due to the Cotrimoxazole prophylaxis which is recommended for people under ART by WHO (18). In addition, HIV people having lower CD4 cells were given IPT (Isoniazid preventive treatment) to prevent MTB. IPT completed people may reduce the rate of isolation of the bacterial pathogen from LRT (17). A relatively higher occurrence of LRT infection was observed in the old age of 61-70 years as compared to other groups ( $p$-value 0.49). The weakness of the immune system with age makes them vulnerable to different types of infections. Macfarlane et al 1993 also reported the same (19). No infection was reported in young participants of age below 20. The infection rate was higher in male participants (27.5\%) as compared to female participants (22.88\%). Similarly, Ojha et al reported the rate of infection in males and females in the ratio of 1.3:1 $(p=0.39)(4)$.

Many predisposing factors are associated with bacterial coinfection in HIV people. A significantly higher rate of bacterial infection (39.8\%) was observed in HIV patients having CD 4 count $<200$ cells $/ \mu \mathrm{l}$ as compared to the least infection in PLHA with CD4 count $>500$ cells/ $\mu$ l. Yadav and Prakash also observed a significantly higher rate of LRT infections (63.4\%) among cases with a CD4 count $<200$ cells $/ \mu \mathrm{l}$, followed by those within the $200-500$ range category $(53.1 \%)$ and least $(18.7 \%)$ in that above 500 cells/ $\mu \mathrm{l}$ (20). The most important risk factor for bacterial pneumonia in HIV people is the degree of immunosuppression which is reflected by the CD4+ T-lymphocyte count (21). On the other hand, a slightly higher rate of bacterial infection was observed in active smokers $(p=0.43)$. In contrast, Yadav and Prakash reported a significantly higher rate of LRT infection among smokers (20). They also concluded that tobacco smoking has been identified as one of the most important risk factors contributing to a higher prevalence of chronic bronchitis and chronic obstructive lung disease in Nepal. Various mechanisms cause increasing susceptibility of smokers to various infections including structural changes in the respiratory tract and decreased immune response (22). Thirdly, a bacterial infection in HIV people previously infected with PTB was comparatively higher than those without a history of PTB $(22.8 \%)(p=0.06)$. Since PTB is a chronic lung disease and leaves patches, pulmonary nodules, or granuloma in the lungs, which might enhance the secondary bacterial infection (23). Likewise, people who were more exposed to the external environment such as shopkeepers, carpenters, tourist guides, security guards, army, police, etc were found more susceptible to LRT infections as compared to other people doing household. The reason might be due to exposure to the polluted outdoor environment.

Among 67 Gram-negative isolates, K. pneumoniae was the predominant one followed by H. influenzae and E. coli. Similar to this study, Ramana et al. and Jemal et al. found $K$. pneumoniae as a predominant one accounting for $45.1 \%$ and $41.3 \%$ respectively $(17,24)$. Few other studies had also reported $K$. pneumoniae as the predominant bacteria causing LRTI among HIV people $(4,25)$. However, Oja-Bola and Oluyege reported $E$. coli (40\%) as the most frequent organism followed by $P$. aeruginosa (35\%) and $K$. pneumoniae as the least (5\%) isolated one (5). K. pneumoniae can cause diseases in non-HIV people as well however pneumonia due to Klebsiella is classically thought to be community-acquired (25). However, 
Mishra and the coworkers reported Haemophilus influenza as the most predominant (21\%) isolate in the sputum of HIV people (26). H. influenzae associated pneumonia is highly associated with a high degree of immune suppression (27).

We found Amoxicillin, Tetracycline and Cotrimoxazole were the least effective drugs against Gramnegative pathogens, however, WHO recommended Cotrimoxazole for the treatment of pneumococcal disease in HIV/AIDS patients. This result was also supported by Oja-Bola and Oluyege (5). They found only $20 \%$ of Klebsiella that were sensitive towards Cotrimoxazole. Similarly, Adeleye et al. reported Cotrimoxazole to be resistant for LRT isolates in Nigeria (28). The resistance towards trimethoprimsulphamethoxazole (TMP/SMX) might be due to the extensive use of Cotrimoxazole by HIV-infected people as their basic regimen for the treatment of opportunistic bacterial infections. In the study, ESBL producing strains were found to be resistant towards most of the drugs used except Gentamycin, Imipenem, Polymyxin B and Colistin. And non-ESBL producing isolates were sensitive towards all drugs except Amoxicillin and Tetracycline.

Plasmid-mediated ESBL producers are nowadays a matter of concern due to their capacity to hydrolyze 3rd and 4th generation cephalosporin and monobactams (29). Decreased susceptibility of Gram-negative isolates towards 3rd and 4th generation cephalosporin could be attributed to ESBL or AMP-C betalactamase production. The most predominant ESBL producer was found to be $E$. coli, P. aeruginosa and Acinetobacterspp followed by $K$. pneumoniae by the phenotypic method. In contrast to our result, $\mathrm{KC}$ et al had reported $K$. pneumoniae (80\%) and $P$. aeruginosa (50\%) as the two predominant species to produce ESBL from the same study site (25).

On amplifying the plasmid-mediated ESBL gene, 23 (43.3\%) isolates gave a positive result. The two isolates that gave positive ESBL test phenotypically contained neither of the two genes amplified. It might be due to the presence of ESBL genes other than targeted ones. This result was supported by de Oliveira et al (30). Another two isolates were possessing ESBL genes but were phenotypically undetectable by combined disk test. This showed the sensitivity of the genotypic method over the phenotypic method. Another reason might be a low level of ESBL gene expression. Gautam et al also reported $40.8 \%$ of PCRpositive ESBL that were phenotypically undetectable (31). They also explained that phenotypic identification of ESBL was based on the inhibition of the enzyme by clavulanic acid, and the inhibitory action of clavulanic acid could be masked due to the co-existence of multiple enzymes. In addition, the co-existence of AmpC enzymes in ESBL producers may alter the pores of the cell membranes, resulting in reduced affinity for $\beta$-lactamase inhibitors for enzymes such as TEM and SHV. Hence, the production of different types of $\beta$-lactamases (TEM, SHV, CTX-M and OXA) by the same microorganism can lead to erroneous phenotypic conclusions.

\section{Study limitation}

All possible ESBL genes were not detected due to lack of time and budget. 


\section{Conclusion}

The lower respiratory tract infections other than PTB by multidrug-resistant Gram-negative pathogens are quite common opportunistic infections deteriorating the quality of life of HIV people. The higher rate of resistance towards WHO recommended broad-spectrum antibiotic, Cotrimoxazole and the presence of drug-resistant genes alarms the rampant use of antibiotics among seropositive HIV individuals.

\section{Abbreviations}

AIDS: Acquired Immune Deficiency Syndrome, ATCC: American Type Culture Collection; ART: Antiretroviral Treatment, AST: Antibiotic Susceptibility testing; BA: Blood Agar; CA: Chocolate Agar, CDC: Center for Diseases Control and Prevention, CLSI: Clinical Laboratory Standard Institute; DOHS: Department Of Health Service; ESBL: Extended Spectrum b-Lactamase; HIV: Human Immunodeficiency Virus, IPT: Isoniazid Preventive Treatment, LRTI: Lower Respiratory Tract Infection, MA: Mac-Conkey Agar, MBL: Metallo b-Lactamase; MHA: Mueller Hinton Agar; MDR: Multidrug Resistance; min: minute/s, PCR: Polymerase chain reaction, PLHA: People Living with HIV-AIDS, PTB: Pulmonary Tuberculosis, STIDHH: Sukraraj Tropical and Infectious Disease Hospital, WHO: World Health Organization

\section{Declarations}

\section{Ethics approval and consent to participate}

The study was reviewed and approved by Nepal Health Research Council (NHRC). A copy of the information sheet and a consent form were given to the participants to obtain written consent before enrollment in the research and collecting samples. A local language translated information sheet was read for illiterate participants. Informed consent was obtained from all the participants and in the case of children under 16 years, both written informed consent with assent was obtained from a parent or a local guardian attending the hospital along with the participant. All the methods were carried out in accordance with the principles stated in the Declaration of Helsinki.

\section{Consent to publish}

Not applicable

\section{Availability of data and materials}

The datasets used and/or analyzed during the current study available from the corresponding author on reasonable request at upendrats@gmail.com.

\section{Competing interests}

We declare no competing interests. 


\section{Funding}

The funding supports for this research work and publishing it is not available

\section{Authors' Information:}

RM Riju Maharjan, M.Sc. Email: rjunewa50@gmail.com

AB Anup Bastola, MD $\quad$ Email: docanup11@gmail.com

NA Nabaraj Adhikari, Ph.D.Email: adhikarinaba13@gmail.com

KRR Komal Raj Rijal, Ph.D. $\quad$ Email: rijalkomal@gmail.com

MRB Megha Raj Banjara $\quad$ Email: banjaramr@gmail.com

PG Prof. Prakash Ghimire $\quad$ Email: prakashghimire@gmail.com

UTS Upendra Thapa Shrestha, Ph.D. Email: upendrats@gmail.com

\section{Authors' contributions}

RM developed the concept of this study and the whole laboratory work was done by herself. The HIV people were convinced and enrolled in the study by $A B$ and also supervised the hospital work at STIDH. The molecular work was supervised UTS at Central Department of Microbiology, Tribhuvan University. The data were analyzed by RM, UTS and MRB. The first draft of the manuscript was prepared by UTS. The review of the manuscript was done by NA, KRR and PG. The final draft was prepared by UTS. All the authors have read and reviewed the manuscript thoroughly.

\section{Authors' Details}

${ }^{1}$ Central Department of Microbiology, Tribhuvan University, Kirtipur, Kathmandu, Nepal

${ }^{2}$ Sukraraj Tropical and Infectious Disease Hospital, Teku, Kathmandu, Nepal

\section{Acknowledgments}

We would like to express our sincere gratitude to all laboratory and technical staff at Antiretroviral Treatment (ART) center, Sukraraj Tropical and Infectious Disease Hospital and Central Department of Microbiology, Tribhuvan University for their generous support throughout the research work.

\section{References}

1. WHO. HIV/AIDS-Fact sheets. 2020. 
2. Vidya Vijayan KK, Karthigeyan KP, Tripathi SP, Hanna LE. Pathophysiology of CD4+ T-Cell Depletion in HIV-1 and HIV-2 Infections. Front Immunol. 2017;8:580.

3. NACO. Guidelines for prevention and management of common opportunistic infections/malignancies among HIV infected adult and adolescents. . National AIDS control organization Ministry of Health and Family Welfare Government of India. 2007.

4. Ojha CR, Rijal N, Khagendra KC, Palpasa K, Kansakar P, Gupta BP, et al. Lower respiratory tract infections among HIV positive and control group in Nepal. Virusdisease. 2015;26(1-2):77-81.

5. Ojo-Bola O, Oluyege AO. Antibiotics Resistance of Bacteria Associated with Pneumonia in HIV/AIDS Patients in Nigeria. American Journal of Infectious Diseases and Microbiology. 2014;2(6):138-44.

6. Dhungel BA, Dhungel KU, Easow JM, Singh Y. Opportunistic infection among HIV seropositive cases in Manipal Teaching Hospital, Pokhara, Nepal. Kathmandu University Medical Journal 2008;6(3):5.

7. Kandati J, Boorsu S, Ponugoti M, Samudrala V. Bacterial and fungal agents causing lower respiratory tract infections in patients with human immunodeficiency virus infection. International Journal of Research in Medical Sciences. 2016:3595-600.

8. Cheesbrough M. District Laboratory Practice in Tropical Countries. Part 2. 2nd ed. 22, editor. The Edinburgh Building, Cambridge CB2 8RU, UK: Cambdrige University Press; 2006.

9. CLSI. Clinical Laboratory Standard Institute (CLSI): Performance standards for antimicrobial susceptibility testing. . 29 ed: Clinical and Laboratory Standrads Institute antimicrobial susceptibility testing standards M02, M07 and M11.; 2019. 118-28 p.

10. Magiorakos AP, Srinivasan A, Carey RB, Carmeli Y, Falagas ME, Giske CG, et al. Multidrug-resistant, extensively drug-resistant and pandrug-resistant bacteria: an international expert proposal for interim standard definitions for acquired resistance. Clin Microbiol Infect. 2012;18(3):268-81.

11. Sambrook J, Fritsch EF, Maniatis T. Molecular cloning: a laboratory manual. 1989.

12. Thapa Shrestha U, Adhikari N. A Practical Manual for Microbial Genetics. 2014:pp-68-92.

13. Edelstein M, Pimkin M, Palagin I, Edelstein I, Stratchounski L. Prevalence and molecular epidemiology of CTX-M extended-spectrum beta-lactamase-producing Escherichia coli and Klebsiella pneumoniae in Russian hospitals. Antimicrob Agents Chemother. 2003;47(12):3724-32.

14. Sharma M, Pathak S, Srivastava P. Prevalence and antibiogram of Extended Spectrum $\beta$-Lactamase (ESBL) producing Gram negative bacilli and further molecular characterization of ESBL producing Escherichia coli and Klebsiella spp. Journal of clinical diagnostic research. 2013;7(10):5.

15. Chandwani J, Vyas N, Hooja S. Antibiotic Susceptibility Pattern of Bacteria Causing Lower Respiratory Tract Infections in HIV/AIDS Patients with Correlation to CD4+T Cell Counts. Int J Med Res Prof. 2017;3(1):6.

16. Chakma S, Majumdar T, Singh NGB. Study of opportunistic pathogens in lower respiratory tract infections among subjects with acquired immune deficiency syndrome (aids) in a tertiary care centre of TripuraAccessed 8 Apr. 2021. Journal of Evolution of Medical and Dental Sciences. 2017;6(31). 
17. Ramana K, Kalaskar A, Rao M, Rao S. Aetiology and Antimicrobial Susceptibility Patterns of Lower Respiratory Tract Infections (LRTI) in a Rural Tertiary Care Teaching Hospital in Karimnagar, South India. American Journal of Infectious Diseases and Microbiology. 2013;1(5):101-5.

18. WHO. Guidelines on cotrimoxazol prophylaxis for HIV related infections among children, adolescent and adults. 2006.

19. Macfarlane JT, Macfarlane RM, Rose DH, Colville A, Guion A. Prospective study of aetiology and outcome of adult lower-respiratory-tract infections in the community. The Lancet. 1993;341(8844):P511-4.

20. Yadav K, Prakash S. Bacteriological Profile of Lower Respiratory Tract Infection (LRTI) among HIV Seropositive Cases in Central Terai of Nepal. Int J Curr Microbiol App Sci. 2015;4(11):12.

21. Mayaud C, Parrot A, Cadranel J. Pyogenic bacterial lower respiratory tract infection in human immunodeficiency virus-infected patients. Eur Respir J Suppl. 2002;36:28s-39s.

22. Feldman C, Anderson R. Cigarette smoking and mechanisms of susceptibility to infections of the respiratory tract and other organ systems. J Infect. 2013;67(3):169-84.

23. Nachiappan AC, Rahbar K, Shi X, Guy ES, Mortani Barbosa EJ, Jr., Shroff GS, et al. Pulmonary Tuberculosis: Role of Radiology in Diagnosis and Management. Radiographics. 2017;37(1):52-72.

24. Jemal $M$, Deress $T$, Belachew $T$, Adem $Y$. Antimicrobial Resistance Patterns of Bacterial Isolates from Blood Culture among HIV/AIDS Patients at Felege Hiwot Referral Hospital, Northwest Ethiopia. Int J Microbiol. 2020;2020:8893266.

25. KC R, Adhikari S, Bastola A, Devkota L, Bhandari P, Ghimire P, et al. Opportunistic Respiratory Infections in HIV Patients Attending Sukraraj Tropical and Infectious Diseases Hospital in Kathmandu, Nepal. HIV AIDS (Auckl). 2019;11:357-67.

26. Mishra SK, Acharya J, Kattel HP, Koirala J, Rijal BP, Pokhrel BM. Metallo-beta-lactamase producing gram-negative bacterial isolates. J Nepal Health Res Counc. 2012;10(22):208-13.

27. Cordero E, Pachón J, Rivero A, Girón JA, Gómez-Mateos J, Merino MD, et al. Haemophilus influenzae Pneumonia in Human Immunodeficiency Virus-Infected Patients. Clinical Infectious Diseases 2000;30(3):5.

28. Adeleye A, Uju L, Idika N, Sobande O. Cotrimoxazole resistance in Streptococcus pneumoniae isolated from sputum of HIV-positive patients. West Indian Med J. 2008;57(5):3.

29. Ur Rahman S, Ali T, Ali I, Khan NA, Han B, Gao J. The Growing Genetic and Functional Diversity of Extended Spectrum Beta-Lactamases. Biomed Res Int. 2018;2018:9519718.

30. de Oliveira CF, Salla A, Lara VM, Rieger A, Horta JA, Alves SH. Prevalence of extended-spectrum betalactamases-producing microorganisms in nosocomial patients and molecular characterization of the shv type isolates. Braz J Microbiol 2010;41(2):5. PMID: 24031491; PMCID: PMC3768689.

31. Gautam V, Thakur A, Sharma M, Singh A, Bansal S, Sharma A, et al. Molecular characterization of extended-spectrum beta-lactamases among clinical isolates of Escherichia coli \& Klebsiella pneumoniae: A multi-centric study from tertiary care hospitals in India. Indian J Med Res. 2019;149(2):208-15. 
Figures

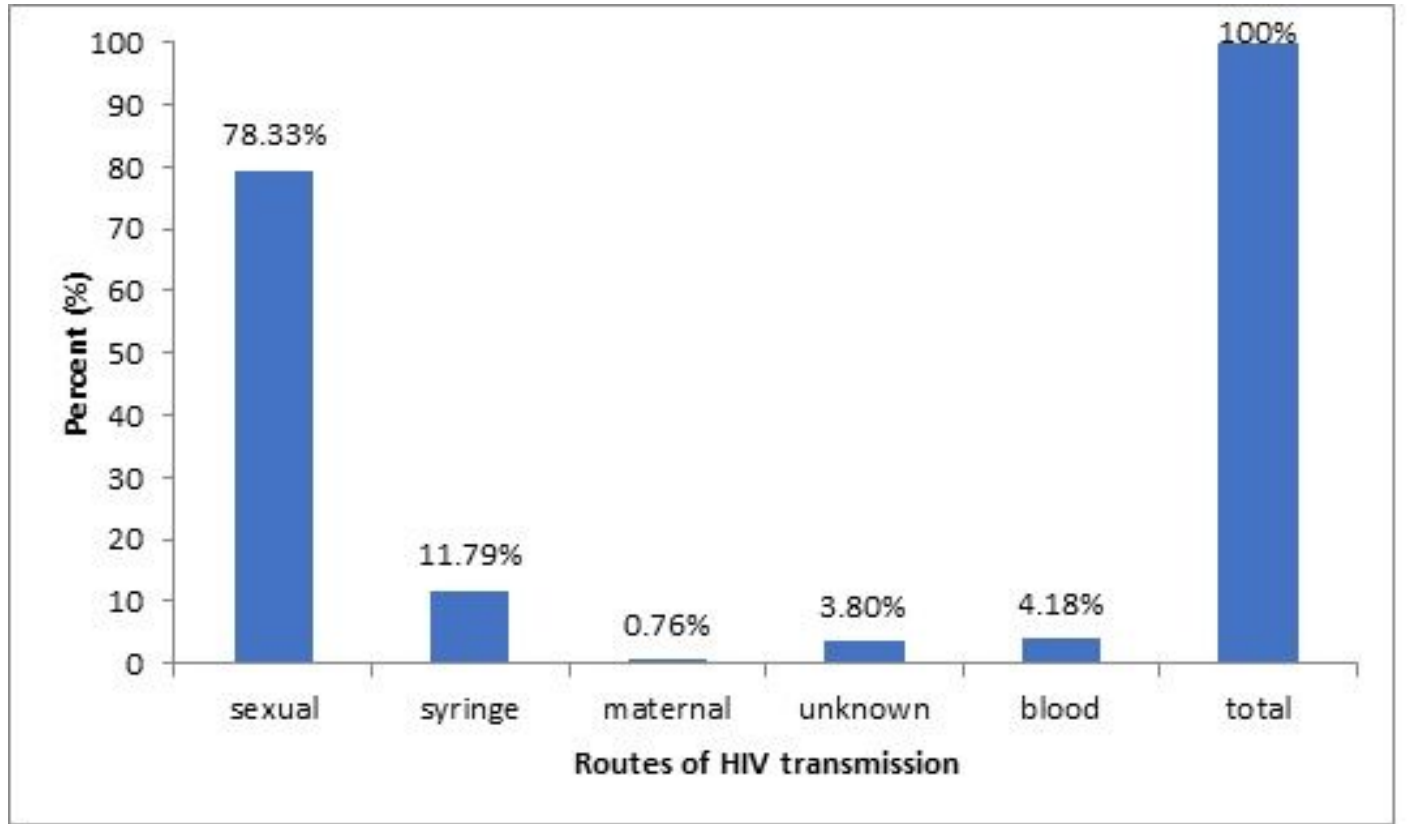

Figure 1

Mode of transmission of HIV among participants

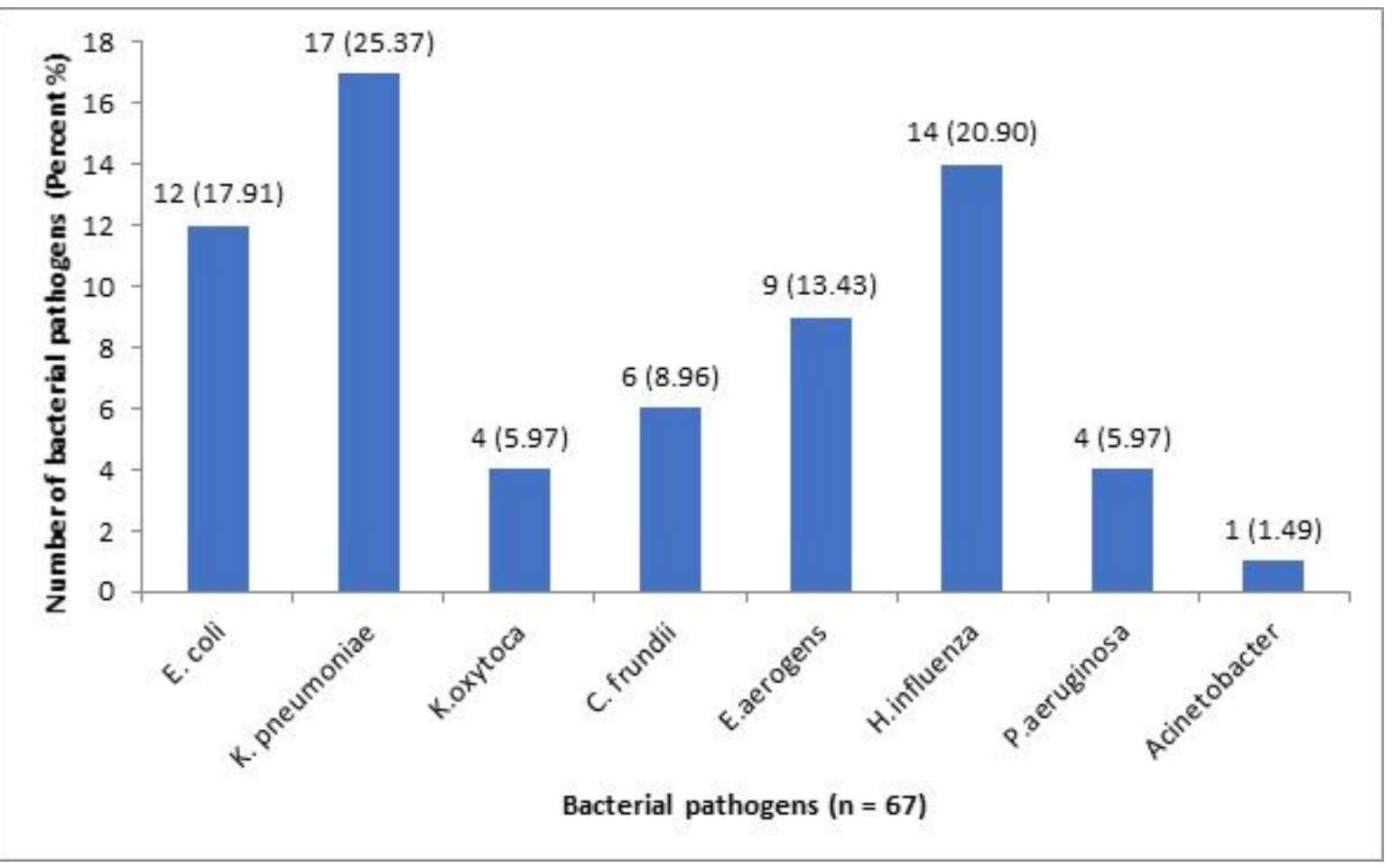

Figure 2

Distribution of bacterial pathogens in LRT infections of HIV people 


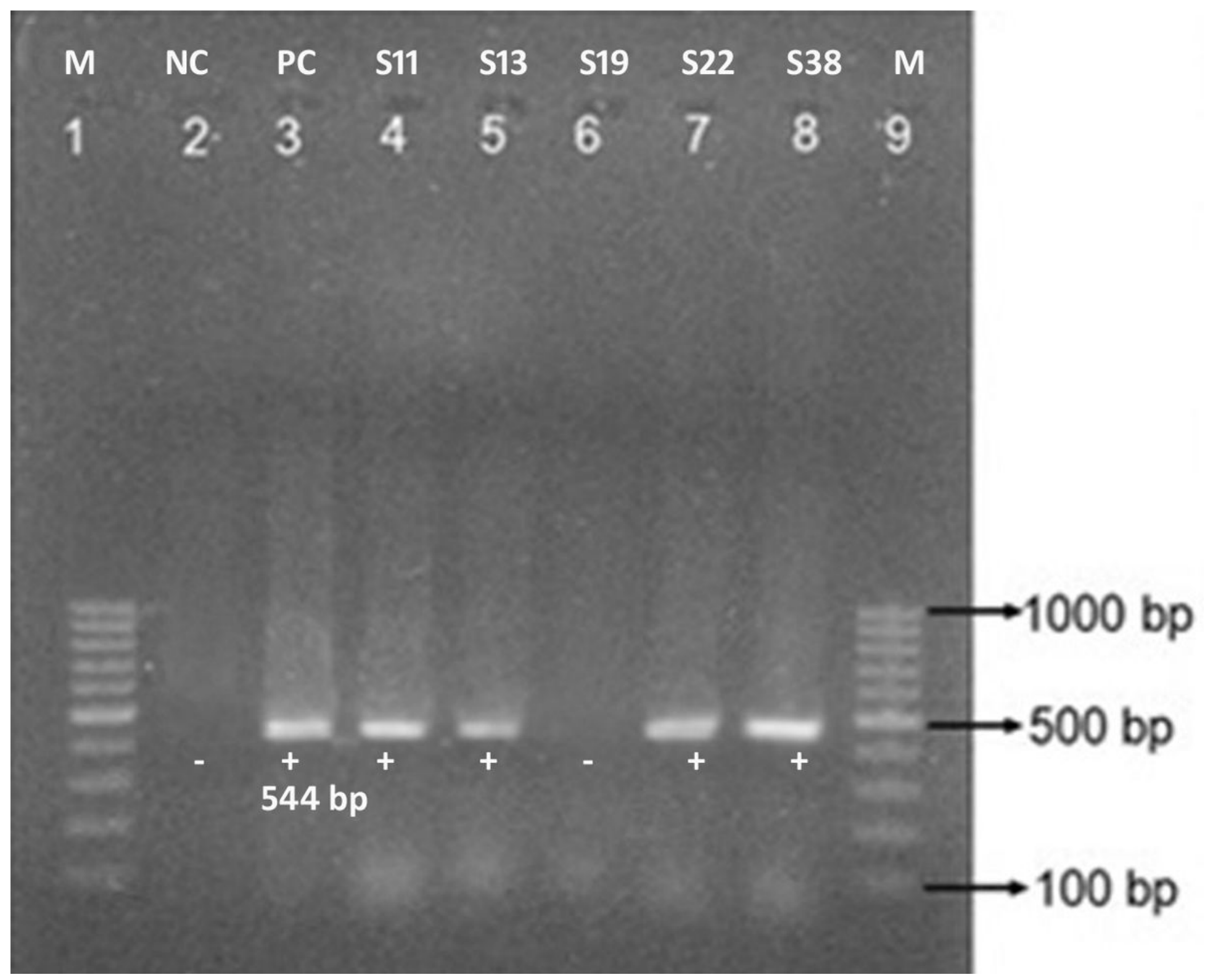

Figure 3

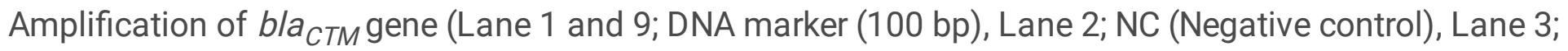
PC (Positive control) and Lane 4-8; gene amplification from isolates) 


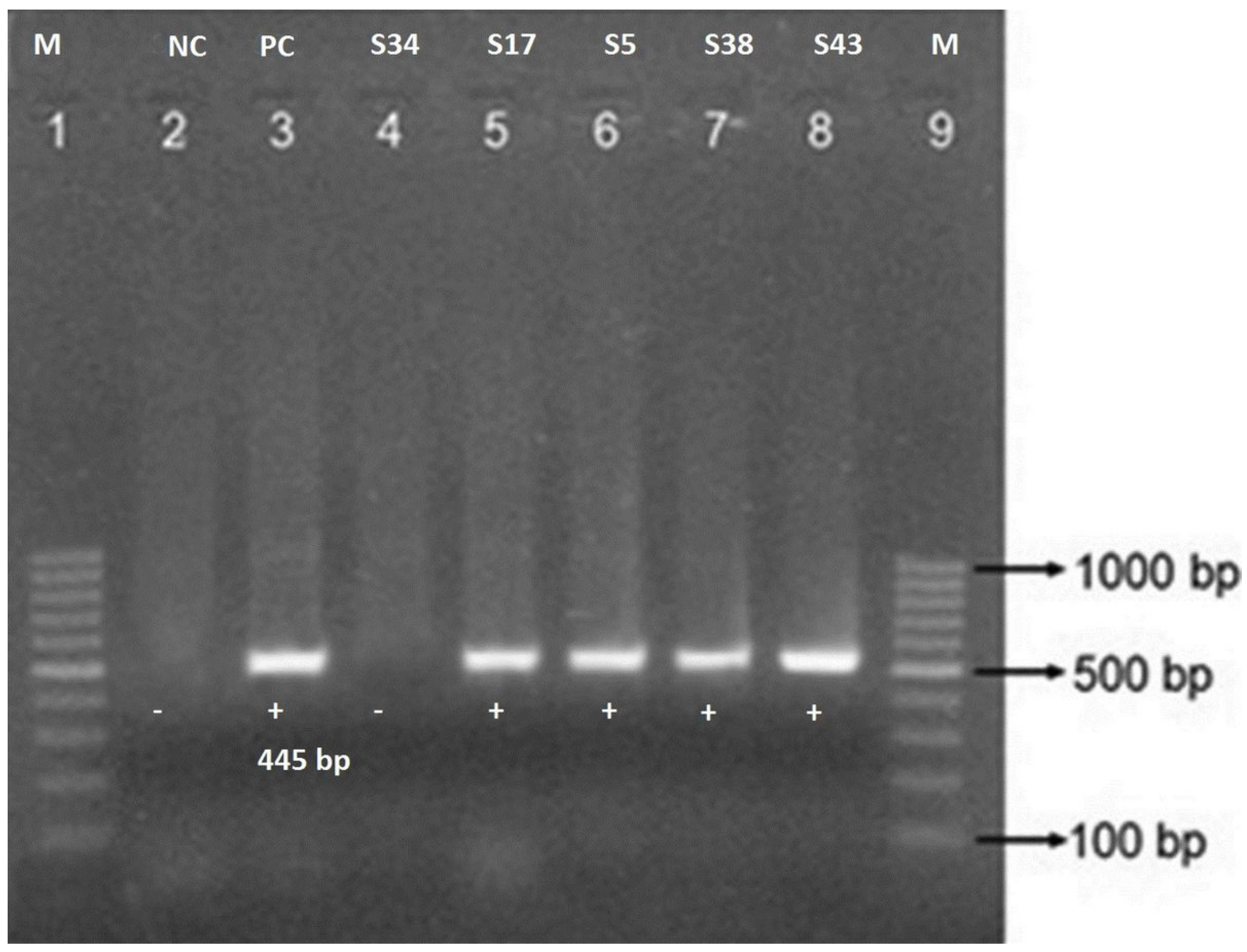

\section{Figure 4}

Amplification of bla $a_{T E M}$ gene (Lane 1 and 9; DNA marker (100 bp), Lane 2; NC (Negative control), Lane 3; PC (Positive control) and Lane 4-8; gene amplification from isolates) 